International Journal of Child, Youth and Family Studies (2011) 3 \& 4: 410-431

\title{
“SINGLE MOTHERS BY CHOICE": DISRUPTING DOMINANT DISCOURSES OF THE FAMILY THROUGH SOCIAL JUSTICE ALTERNATIVES
}

\section{Jennifer Ajandi}

\begin{abstract}
This paper seeks to disrupt the dominant narrative of victimhood associated with the single mother family status. There are many barriers and difficulties associated with this status such as economic insecurity and political and social stigma. However, there are also many rewards and possibilities that make this family status desirable and rich with possibilities. Single mother families challenge the dominant paradigm of heteronormativity found within the notion of traditional nuclear family households. Drawing on critical feminist and queer theoretical perspectives and qualitative research from my doctoral studies, I will discuss how participants created a new narrative for themselves and their children. In particular, I focus on single mothers engaged in critical pedagogy and curriculum and community activism to seek connections with others who also viewed their families from a strengths perspective. "Single mothers by choice” establishes itself in its own right as a formidable alternative to dominant notions of the "family".
\end{abstract}

Keywords: single mothers, dominant discourse, strengths, social justice

Jennifer Ajandi, Ph.D. is a Sessional Instructor in the School of Social Work at Ryerson University, 350 Victoria Street, Toronto, ON, M5B 2K3. Email: jajandi@ryerson.ca 
"Single mother." Say it out loud in a grocery store, at school, in the park, on the news, or in a social service agency and all of the destructive and pathologizing images of a neglectful mother come to mind. The stereotype of the single mother intersects class, race, gender, sexuality, ability, and age. It is a deeply racialized image that presents a false and simplistic picture of a single mother dependent upon social assistance (Bashevkin, 2002; Mitchell, 2003; Sidel, 2006). The discourse of the "welfare queen" pervades everyday dialogue, political commentary, and the ideologies prevalent in social service delivery, the education system, and the broader community (Jones-DeWeever, 2005; Roberts, 1999). Within this discourse, the single mother household becomes responsible for all that society deems morally unfit and undesirable. Children raised in single mother households become scapegoats for a perceived increase in crime rates, a breakdown of social cohesion in communities, and "early" pregnancy, just to name a few examples.

The effects of ideologically conservative and punitive social policy attacks on marginalized populations become masked when individuals or groups of people are blamed for their own dire circumstances. A discourse of individualism dominates the political landscape wherein privilege is hidden and success is therefore achievable by anyone who tries hard enough (Brady, 2007; Carniol, 2000; Mullaly, 2002; Waldner, 2003). Blaming the individual becomes a political strategy to cover up the inequitable distribution of resources and power (Carniol, 2000). Given the many injustices that marginalized people face, such as racism, economic insecurity, food insecurity, ableist structures, heterosexism, and discrimination based on family status, the resilience and resistance employed on an everyday basis is remarkable and worth noting.

In this paper, I discuss the difficulties and possibilities of 25 single mothers attending university across Southern Ontario, Canada. These findings are based on my doctoral research, which addresses a large gap in Canadian and U.S. literature. I provide a brief analysis of the barriers that were reported but the majority of the discussion focuses on the strengths, aiming to develop a positive alternative discourse to the prevailing stereotypes of single mothers, despite their status as one of the most economically disadvantaged groups (Bezanson, 2006; Caragata, 2009), particularly for single mothers of colour (Khosla, 2008) and single mothers who are Aboriginal (D. Lavell \& J. Lavell, 2006). This alternative discourse does not make the struggles and challenges of single mothers invisible but highlights parts of their lives that are often not reported or not asked about in research studies. In some instances, I even dare to put forward the notion that single mother households might be more constructive and healthy than some traditional, heterosexual, and two-parent households. At the very least, these family structures have positive characteristics of their own in contrast to the many negative ones commonly put forth by the dominant discourse, a reality that deserves attention in its own right and might ultimately legitimize the single mother family status. Most women in this study did not apologize, feel ashamed, or feel that their families were "less than" their two-parent counterparts. On the contrary, they thrived, felt grateful for their struggles and joys, and believed that their families were representative of and contributors to the larger social justice goals of equity and inclusion. 
International Journal of Child, Youth and Family Studies (2011) 3 \& 4: 410-431

\section{Reflection}

I write about issues that arouse passion, connection and a drive to action within me. In the same way that I need to connect to practice, volunteerism, and teaching (praxis), I also need to connect to the issues I research and to the overall research process itself. Women have invited me into their lives, their pains, and their joys with a sometimes unearned trust that humbles me. I take the role of a researcher and an "insider/outsider" quite seriously. In this study, it was important that I identify who I was, who I was not, and be critical of my own social location and the inscriptions of history, power, oppression, and privilege on my body. Throughout my dissertation I wrote in a reflective way, paying attention to social location, privilege, and transparency. At times, the stories I shared in my study were ones I shared with the women who participated.

When writing about equity and social justice, it is important for me to also challenge the dominant constructions and deliveries of scholarship that permeate some fields such as child, youth, and family studies and social work. Students often comment on my use of accessible language and how I ground my work in personal narrative which, in turn, assists them in making connections to their own lives. The writing in this paper reclaims the personal and experiential in the spirit of critical feminist, anti-colonial, and other theoretical frameworks and areas of research that are committed to transformation and social justice (Potts \& Brown, 2005). Transparency and reflexivity are integral to the research process, including the dissemination of the research itself. Undertaking a commitment to social justice not only involves the counter narratives and discourses we create but also challenges the dominant Eurocentric ideologies, practices, and expectations in academic institutions (Smith, 1999). My position as an activist scholar is that by identifying the voice of the author and researcher, I aim to disrupt the dominant norms of "objectivity" commonly found within academia. Further, this voice is not regulated to one section or compartmentalized, but is integrated throughout.

My own experience as a queer single mother (beginning in the third year of my undergraduate degree, continuing into my graduate studies, and now into my career as an academic) guides my own analysis and structures my views of society, the education system, and the institutions of the family. The invisibility and stigma I felt on-campus as a single mother student and recipient of social services, especially during those first few years, were palpable, painful, and transformative. For quite literally months on end, I would sleep no more than two hours at a time and averaged four hours a night until the last year of my doctoral degree. Single mother students are simply on a 24-hour shift.

The intangible stigma of being a single mother impacts my access to housing and my daughter's experience in the education system. The last time I looked for a place to rent, one of the first questions I was asked was who would be living in the space. I answered myself and my daughter. The next question I was asked each time was if I was on social assistance. I was repeatedly turned down on applications even though I had the privilege of holding a high status occupation in the community. Despite the struggles I have encountered, the privileges I hold impact my ability to access the limited resources available. I know that had my body been read 
differently, had I been a Black single mother, had visible physical disabilities, or received social assistance at that time I would have received even more hostile comments and less access to resources. I reflect on and engage in this privilege, knowing that I have the power in the classroom to dispel the myths, stigma, and dominant discourse that constructs single mothers and other marginalized groups in society. Wehbi (2009) notes the importance of thinking and writing about our reflections on teaching in social work classrooms: "Over the years, I have come to understand reflection on our practice as social workers in the field, or as educators in the classroom are both significant sources of knowledge worthy of writing about. These are our 'field' stories to tell” (p. 506). I work as an ally to disrupt dominant discourses and listen to constructive feedback from colleagues, community members, and students (Bishop, 2002). Now that I am the first in my family to graduate from university, I am both uncomfortable with the new resources I have and grateful for them. My story, as well as the stories of the women who participated in the study, disrupts the dominant discourse of single motherhood, yet I do not strive to perpetuate the binary of the "deserving" versus the "undeserving" single mother (Abramovitz, 1996; Ajandi, 2009); this paper aims to start a different dialogue.

\section{Reviewing the Literature and Theoretical Contributions}

Previous research explored single mothers' experiences within the context of the state, with a main focus on the barriers erected due to changes in oppressive state policy in the United States. This subject remains underrepresented in the Canadian literature and this study's aim is to start filling in that gap. Across many countries, neo-liberalism and the corresponding rise in neoconservative political ideology has impacted the way the state supports or does not support its citizens (status and non-status). With an increase in global market demands and a pressure to reduce deficits, states are clawing back much-needed supports and services to its most marginalized communities. A reduction in funding to the social service sector alongside an increasing emphasis on managerial matters in the social work profession has had devastating consequences for service providers and service users (Fook, 2002; Ife, 1997; Razack, 2002; Rogowski, 2008). With the social service sector beginning to look more and more like business, not only are the values and principles of anti-oppressive social work being eroded, the voices and needs of the service users are being lost as well. Among its many principles, anti-oppressive social work values self-determination, disruption to power hierarchies, advocacy, and activism (Barnoff \& Moffatt, 2007). In an accountability climate that values evidence-based practice, output measures, and cost-effectiveness at the expense of true anti-oppressive work, it is more and more difficult for social workers to avoid feeling overwhelmed and susceptible to burnout, compassion fatigue, vicarious trauma, etc. (Fook, 2002; Ife, 1997; Razack, 2002).

The majority of previous literature focuses on conservative measures that were implemented to social assistance in the 1990s in the U.S. that, in effect, placed severe restrictions upon single mothers who received social assistance and wanted to pursue post-secondary education (Adair, 2001; Pandey, Zhan, \& Kim, 2006; Pandey, Zhan, Neely-Barnes, \& Menon, 2000). Programs, supports, services, and monies that were used to support families with dependents were drastically changed and recipients were instructed that they had time limits on how much education they could receive. The exact time limits varied from state to state but in most cases they restricted recipients' ability to participate in any long-term, meaningful education that could quite possibly improve their economic situation (Jones-DeWeever, 2005; 
International Journal of Child, Youth and Family Studies (2011) 3 \& 4: 410-431

Zhan \& Pandey, 2004a). It is well documented that attaining post-secondary education results in higher incomes and is, moreover, becoming a necessity for even entrance level positions (Lightman, Herd, Um, \& Mitchell, 2009; Zhan \& Pandey, 2004b). While receiving postsecondary education is not the end-all solution and does not address barriers that women experience in the paid labour market such as racism, sexism, ableism, heterosexism, ageism, family status discrimination, etc., it has been shown to provide some economic stability. Changes to social assistance policies that reduce access to education should be seen as a violation of a person's rights.

Canada, and more specifically the Province of Ontario, saw similar cuts to its social safety net in the 1990s based on neo-conservative individualistic ideology. Part of this ideology was demonstrated in targeted cuts to programs and services serving some of the most marginalized members of society: those experiencing violence; children; racialized people; and poor people (Lightman \& Baines, 1996). Cuts to the education system were also devastating; tuition rates in Ontario dramatically increased (Bezanson, 2006; Rajagopal, 2002; Shanahan \& Jones, 2007; Schwartz \& Finnie, 2002). Previously, students could apply for social assistance to meet their living costs and student loans to assist in their educational costs. Now, for the most part, students cannot collect both benefits at the same time. Since a greater amount is received from student loans than from social assistance, most people choose that option. However, interest rates on student loans are considerable and graduating with such high debt loads puts students at a disadvantage (Statistics Canada, 2006). My own debt load from years of post-secondary education, for example, will take at least 15 years to repay. This is a best case scenario and demonstrates my own privileged position as a university instructor, as many graduates will not earn enough from their paid employment to repay their loans within this time frame.

While changes in social policies have taken place over the last 20 years, the dominant structure of Eurocentrism found in many Canadian educational institutions is far longer-standing and more entrenched. This type of education focuses on one standardized way of knowing and learning, ignores accurate history or makes it invisible, and excludes diversity in curricula, policies, practices, and bodies on-campus (Bannerji, Carty, Dehli, Heald, \& McKenna, 1991; Baskin, 2005; Brathwaite, 2003; Carty, 1992; Collins, 2000; Dei, James, Karumanchery, JamesWilson, \& Zine, 2000; Giroux, 2002; Kelly, 2000; Kitzinger, 1993; Mojab, 2002; MontureAngus, 2001; Oliver \& Barnes, 2010; Rezai-Rashti, 1997; Sapon-Shevin, 2007). Anti-racist and anti-colonial educators and activists challenge these practices and advocate for inclusionary spaces centring on multiple voices and ways of knowing (Abele, Dittburner, \& Graham, 2000; Antone, 2003; Dei et al., 2000; Baskin, 2008; Collins, 2000; Graveline, 1998; Henry \& Tator, 2009; hooks, 1994; James, 2003; Mahtani, 2004; Ng, Staton, \& Scane, 1995; Reed, Lewis, \& Lund-Lucas, 2006; Wong, 2004). While women of colour and Aboriginal women discussed these issues most frequently during the interviews, some White women also identified Eurocentrism as a barrier in their educational experience. They preferred to study in fields or classes that were taught by Aboriginal professors, focused on Aboriginal world views in the curriculum, and/or used anti-colonial pedagogical approaches. They found that their life experiences were more valued in these classrooms and they connected with a way of teaching that was more holistic than that of more traditional classrooms. 
Eurocentrism rests on a number of assumptions found throughout society, including a dominant discourse of motherhood that places all responsibility of children onto mothers. This discourse expects mothers to be economically independent from the state, to be the "right age", to have partners (preferably husbands), to devote all their time to their children at the expense of their own needs, and to have just enough children. When a mother does not fall into these unrealistic, middle-class, Eurocentric norms, she becomes the undesirable Other mother (Anderson, 2000; Berman, Silver, \& Wilson, 2007; Cull, 2006; Dua, 1999; Kelly, 2000; Khosla, 2008; D. Lavell \& J. Lavell, 2006; Little, 1998; Pillow, 2004; Wane, 2000). A discourse involves all the ways in which language and symbols are constructed and used by players such as the government, media, and the community to impact ways of knowing and interacting (Fook, 2002; Kelly, 2000). According to Griffith and Smith (1991), discourse is:

An organization of relations among people participating in a conversation mediated by written and printed materials. A discourse has a social organization of authorities, sites, production processes, etc. The term does not just refer to the "texts" of this conversation and their production alone, but also to the ways in which people organize their activities in relationship to them. (p. 90)

Oftentimes, the single mother is socially and politically conceptualized within an eitheror dichotomy in absolute terms. She is constructed as a heroine (Sidel, 2006), who has somehow managed to overcome all obstacles by just trying hard enough, which dismisses the very real economic, political, and social limitations placed upon single mother families. Or, she is constructed as a marginalized and vulnerable victim who is at the mercy of state policies and the processes of social exclusion (Brady, 2007; Caragata, 2009), with little acknowledgement of the resistance, strength, and agency of single mothers. The more accurate representation of single mothers is somewhere in between or at least somewhere on a continuum. They exist in a complex and nuanced reality of ambiguity and fluidity.

In this paper I use a critical feminist queer theoretical framework that intersects with race, class, and ability, to understand and explain moments of disruption to a traditionally heteronormative conceptualization of the family (Reid, 2004; Peters, 2005). These moments of disruption are meant as challenges to normative constructions but also to provide an alternative discourse of the family using examples of social justice. The purpose of this paper is not to ignore or under-represent the overwhelming barriers single mothers face in society - racism and other forms of discrimination, poverty, stigma, and an assaulting policy platform by the state for these findings were well documented in my doctoral research. Rather, I would like to offer a more comprehensive picture of the experiences of single mothers using a strengths-based analysis focusing not only on the troubles, but also on the rich possibilities of single motherhood as a legitimate constructive family status. Also, I hope to uncover an alternative dialogue that supports this status within an equitable and desirable context and challenges the dominant discourse of victimhood. Importantly, this study also contributes to the literature by providing a Canadian context to the experience of single mother students, as the majority of the literature emerged in the United States and frames single mothers as being dependent upon the state through the delivery of social assistance. 
International Journal of Child, Youth and Family Studies (2011) 3 \& 4: 410-431

\section{Design and Methods}

I feel privileged being able to witness the struggles and rewards single mother students have experienced. I feel honoured that women spent so much of their limited time and energy contributing to this important and under-studied research area. The research questions were:

- What are the experiences of single mother students?

- What are their barriers and facilitators?

- Do single mothers experience discrimination?

- What are the strengths of these identities, histories, and households?

Women had the opportunity to participate in either an individual or group interview. I found having both options available was important. During individual interviews the sense of anonymity provided a space where women discussed serious issues of violence, for example. Yet, the group interview was important as well and decreased the amount of power I held as the researcher. Participants have more control over the direction of the conversation in a group setting and the researcher's position shifts from interrogator to facilitator and listener. This method can also be more comfortable for participants when the researcher is unknown to them. Salmon (2007) also found that participants in her study preferred this method, noting "They felt that this would give them additional support, encouragement, and an increased sense of safety and trust in an interview with a researcher who was previously unknown to them” (p. 985). However, the lack of time available to meet the scheduling demands of the group interview proved to be a significant barrier in this study and, as a result, more individual interviews needed to be scheduled.

The first 25 women who expressed interest and met eligibility criteria participated in group and individual interviews. Women identified as single mothers also needed to be full-time undergraduate university students or recently graduated. Throughout the process, women identified the need to meet other single mother students. As a result, we started a social/consciousness-raising group outside of the research. Questions were open-ended and subjects had the opportunity to participate in the research in a number of ways: They could make suggestions about the interview guides; participate in the social group; review and approve their transcripts, as well as contribute to the summaries of the findings; attend a member check-in session at the end of the research; and make other suggestions pertaining to their interest in the study and time they had to contribute (Kirby \& McKenna, 1989; Potts \& Brown, 2005; Reid, 2004; Ristock \& Pennell, 1996; Wilkinson, 1998). Data was analyzed using descriptive and analytic coding with particular attention paid to the emergence of multiple themes (Ristock \& Pennell, 1996). I received Ethics Approval from three universities and a community agency. Because the study involved Aboriginal single mother students, one university also required a separate Ethics Approval submission to their Aboriginal Advisory Circle, which was approved. I approached many on-campus groups who also assisted in the distribution of the call to participate.

Researchers might identify themselves as being either an insider to the research or an outsider (Smith, 1999). An insider is seen as someone who identifies as part of the community they are doing research with, whereas an outsider is someone who has no connections to the community. But what does it mean to be "part of a community"? Single mothers are not a 
homogeneous group, just as “communities” are not. Depending on who I am working with, we might find similarities and differences that work in a fluid and unfixed expression of power (Foucault, 1977). I do not face systemic oppressions such as racism and discrimination based on immigration status. My life experience is different from those of single mothers of colour and single mothers who are Aboriginal, and I needed to acknowledge my white privilege and outsider status. Yet, on many occasions, having some amount of insider knowledge contributed to the trust that was built over the course of the partnerships. Stories were shared on both sides that might be read by the dominant discourse in a different way than the speaker intended. We were also able to strategize and problem-solve issues related to parenting or education that might not have happened without the shared foundation of being single mothers and students.

However, Smith (1999) also cautions us as researchers not to rely on dichotomous interpretations of insider and outsider experiences and reminds us to critically reflect on our own privilege within the partnership. Fook (2002) further challenges us to refrain from using dichotomous and binary terms that can hold false assumptions. Acker (2001) also points out that an insider status can be detrimental to the interview process if participants fail to discuss issues in the same way since they may assume the researcher already knows what they are talking about.

\section{Co-participants}

All the women in this study identified as single mothers and were attending university in an undergraduate program, with the exception of two who had graduated in the past few years. They ranged in age from 25 to 44 and had children as young as 1 year of age and as old as 21 years of age. Participants studied in various disciplines; however, many of them were in Social Work, Aboriginal Studies, Sociology, and Women and Gender Studies. It is likely the findings of this study would be different had the majority of students belonged to other disciplines.

The previous, limited amount of research exploring single mothers and education has not brought attention to the many diverse voices of women participants. In order to provide a more accurate and representative picture, I emphasized diversity during the recruitment stage. The result was a fairly broad spectrum in terms of race, ethnicity, sexuality, age, immigration status, and spirituality. However, economically, most of the women experienced poverty: Seven of the women stated that they earned less than $\$ 10,000$ per year and another 14 less than $\$ 30,000$ per year. Although given their student status this might be expected, it is important to note that some of these women worked full-time or had multiple part-time jobs. Contrary to the dominant narrative of single motherhood, almost three-quarters of the women relied upon student loans for financial support and only two women were receiving social assistance. The implications inherent in state's lack of support through social assistance to university students deserves more attention and the consequences of such policies need to be explored in future research.

Participants were born in many countries, including Canada, the Caribbean, China, Holland, Pakistan, Poland, Scotland, Senegal, Ukraine, Uganda, and the United States. Some women wanted to have these places remain broadly described in order to protect their anonymity. In a demographic questionnaire, the women were asked to self-identify their race and ethnicity. Some of these identities included Black, Black and Indian, Canadian/Jamaican, Caucasian, Chinese, Dutch, Ghanaian, Goan, Irish and Aboriginal, Jewish and White, Native and White, and White with biracial children. Much diversity was represented in spirituality as well. 
International Journal of Child, Youth and Family Studies (2011) 3 \& 4: 410-431

For example, women identified their spirituality as Earth-based and Wicca, Catholic, Christian, Atheist, Agnostic, Not Sure, Karma, Buddhist, and Christian and Aboriginal Traditions.

One of the interesting findings from the study, which is also demonstrated by the demographics of single mother students, is that almost $25 \%$ of the women were exploring their sexuality and were able to do so because they felt liberated from the confines of previous traditional heterosexual partnerships. Women identified as Heterosexual, Bisexual, OpenMinded, Not Sure, Queer, and Two-Spirit. Also, seven women identified having a disability including mental health, physical, and learning disabilities. Three children of single mother participants also had disabilities. The following sections outline some of the main findings from this research with a focus on the strengths of single mother families and connections to social justice.

\section{Independence and Empowerment}

Many women felt privileged to be single mothers because it gave them the freedom to be the sole decision-maker for the family. They were able to raise their children with their own values and did not need to negotiate these decisions with a partner. Participants commented on how much better off they sometimes felt when they witnessed how their friends argued with their partners about how to raise their children or the division of household work and child care. Many women mentioned how much work was involved in taking care of the house, children, and partners when they were in relationships. Some women felt that even though they experienced barriers and being a single mother student was a 24-hour job, not having the other partner to take care of reduced their burden significantly. When Christina and her partner were still together she discussed her 24-hour shift when she was working overnights at a Tim Hortons.

Jenn: So you had mentioned in the first year it was basically you that raised your child, did the carework involved with the baby. Does that mean you were doing all of the unpaid work in the house as well?

Christina: Absolutely.

J: Did you work for pay at all during this time? You had mentioned you worked for Children's Aid?

C: Right. That was after, I did actually when my son was about 6 months old I started working nights at a Tim Hortons in Paris just because we needed the money essentially; so his dad would work during the day and would get home around whatever time, 6 o'clock at night maybe and I would work 11-7.

J: Overnight?

C: Umhum, 11-7; so my son was sleeping through the night consistently enough at that point that he may have gotten up once or twice but consistently enough that I would go 11-7 and be home at 7 in the morning and he would still be sleeping so I would just get him and bring him into bed with me because he would sleep longer if he was in bed with me (laugh) and then his dad would leave for work and he was still taking a morning nap; so he would get up at 8 or 8:30 and we would be up for a bit and then he'd lay down for his nap and I'd lay down with him then get up for lunch so it was really hard.

J: When did you sleep? 
International Journal of Child, Youth and Family Studies (2011) 3 \& 4: 410-431

\section{C: I honestly don't know how I did that either.}

Eichler (2010) defines household work as "the sum of all physical, mental, emotional, and spiritual tasks that are performed for one’s own or someone else's household, and that maintain the daily life of those for whom one has responsibility for" (p. 36). Christina also discussed how much work it was when she lived with her partner and how time away from home at her place of work was like "a break" for her:

I consider myself the only caregiver in the home really because his father wouldn't take him on the weekend with him. He wouldn't. I remember one time I had been stung by a bee. I have an allergy to bee stings. Not life threatening but I swell up a lot. So I had been stung by a bee and I just wanted to go to the grocery store and get an antihistamine and even that was an argument - to have him stay with his dad, right? Because I just wanted to get the heck into the car and get over to the drug store cause it was here in my ear (points to her ear) and I could feel it swelling down my neck and I just want to go over to the grocery store and get the antihistamine because, for whatever reason, we didn't have any in the house. And there was an argument - why do I need to leave to go do that and why couldn't I take him with me, and that kind of crap. He just never took him. So I think going to work when I started working at night was my little break for me because I was not in that sole caregiving role. I had time to myself, it was quiet. I don't know that I would want to work at Tim Hortons again but at the time it was the night shift and there wasn't a whole lot going on. I could just clean, there was the baker in the back and me at the front and we'd just go through the night and the odd customer would come in. That was the break for me.

Overall, feelings of independence contributed to elevating their perceptions of selfesteem and self-worth. The obstacles they overcame daily gave them the strength and resiliency to believe in themselves in ways that they often did not when they were in relationships. Gemma found strength in her role as a student in the education system. As she described it:

It's freedom, it's an opportunity for me to shine in an area that has nothing to do with family or home. And if you put the work in, you get the rewards back. I mean in my marriage, there was very little self-esteem building, confidence building, there was very little affirmation - well none basically...I walk through these halls and I feel so liberated, in control of myself, on a path, and part of something.

Women were also able to advocate for themselves and their children. Many times, women had to fight for their children's rights within the school system due to racism, ableism, heterosexism, and single mother stigma. In some situations, this advocacy occurred within the school they attended and in other situations women had to transfer their children to a more inclusive school. Even though they often encountered discriminatory attitudes and systemic barriers, they felt confident in their agency. Meena spent much of her time advocating for her son in school before she decided to switch him to another school: 
International Journal of Child, Youth and Family Studies (2011) 3 \& 4: 410-431

The school, it was predominately White and I felt the principal, vice principal, right down to the teachers, had strong racist undertones. The way they even spoke about him, "sitting like a possum" and taking away marks because he didn't speak loud enough - because he is very soft spoken. There were so many things, even the way that they spoke to me in their condescending manner. I expressed if this is any indication of how they speak to my son, I can see why he was traumatized. And instead of looking at what was going on there, they suggested something must be wrong in my home...Once I made the decision to remove him, they were like, "oh, we're sorry to see him leave". I'm like, "let's be real, you have traumatized him"; he went from the school that he was at getting high grades to being "at risk" in a matter of months and then when I moved him to the school that he is currently at, his grades are back up. So I said to them, "Do you not see that he came here with high grades and dropped in a short time?" Do you not see something going on here? You're just going to automatically assume that it is something within my home as opposed to something within your school system?

\section{Violence}

The prevalence of violence was one of the most prominent findings in the study, despite no questions about violence being included in the discussion guides. Many women discussed experiencing emotional, psychological, physical, sexual, and financial violence at the hands of their ex-partners. In some situations, the violence was still occurring even after they had left. One month prior to our interview together, Julianne's ex-partner had picked up their son for a weekend visit and began using derogatory language towards her and calling her names. While he was holding their young son he slammed her against the wall. When I asked Julianne how she felt about him having access to visits with their son, she said, “ I don't think he's going to kill him, so I just have to hang onto that - he'll come back to me alive....”. After leaving their relationships, women knew they had no other means to support themselves and their children; they felt that going to university was the only chance to provide financially for their children. I was particularly surprised at the lack of support that many women found in their friends and family when they left the violent relationships. Those around them often encouraged them to go back to the relationships to avoid becoming single mothers. Being a single mother, it seems, was perceived as being worse than experiencing violence. Given the prevalence of the problem, the lack of research examining violence and the student experience is also surprising, with the exception of Eyre (2000), Wagner (2008), and Wagner and Magnusson (2005).

\section{Reciprocity and Giving Back to the Community}

Ideals of reciprocity and giving back to the community are common among many cultures and, not surprisingly, are a prevalent theme in the social work and child, youth, and family studies courses I teach. Many students identify a pivotal point of turmoil in their lives when they needed support from friends, family members, community and/or social support workers. These experiences often provide much of the foundation for wanting to give back to the community and support others in non-judgemental ways. Many students focus on the populations 
International Journal of Child, Youth and Family Studies (2011) 3 \& 4: 410-431

or fields that they were or are involved with in order to share their understanding and life experiences with others.

The women in this study also emphasized these principles in similar ways to social work students in my classroom. Volunteer work, community involvement, and giving back to those with similar experiences were driving forces in their educational endeavours and personal lives. Many were culturally, socially, and politically active in their communities. They valued these experiences and saw them as integral to child-rearing practices. Some even spoke about the activist work they did with their children and bringing their children along to protests.

Reciprocity was a key element in women's positive experiences as single mothers because their understanding, compassion, and empathy for others sprang from the obstacles they faced, even those as trying as systemic discrimination and oppression. Elizabeth explained:

Well, you know what, that's why I'm in school. I'm here for people who have experienced anything that I've experienced, that's why I'm here. I don't know what I'm going to do when I'm done but I have a passion for women, especially women on the streets, single mothers, and mothers who have lost their children.

Even though many women said that caseworkers, professors, or other social support workers contributed to the systemic oppression they experienced such as racism, ableism, and heterosexism, they had also met workers and professors who went out of their way to be supportive allies. The important roles these people played in their lives contributed to their sense that they needed to give back to the community and fill such a role for someone else.

\section{Social Justice and Becoming an Ally}

Many single mother students became activists and advocates against oppression and structured their families to be active in social justice issues. For example, Karina viewed her family as a queer family and was involved in local initiatives that brought awareness to this family status. She was connected with other moms who were both partnered and not within a queer context. This experience was freeing and something she felt she might not be able to do if she were in a traditional heterosexual partnership. However, her political awareness did not end there. She was involved in becoming an ally through anti-racist work and wanted her son to be raised in a social justice environment where he saw how oppressions were linked and understood how important it was to fight against injustice. As Karina noted, "Social justice isn’t just about fighting for equity and inclusion in one community, but seeing how all communities are linked and learning how to become an ally - all injustices are interconnected.” Many women also resented being met with pitied responses when people found out they were single mothers. Several women defined themselves as "single mothers by choice."

Some women were not only exploring the benefits of raising their children in single mother households but were also exploring sexuality. When partnered in heterosexual relationships, most women were unable to explore this or even discuss it with their partners, which produced isolation and fear. Heterosexism is prevalent in many social and political institutions and people with non-normative sexualities and gender identities are still met with 
hostile resistance and discrimination, particularly when their identities intersect with institutions of the family. While the movement for equal marriage rights has gained momentum and made great strides within some parts of Canada and globally, queer parental rights are still an issue (Epstein, 2009a). Some women who had their children with a heterosexual partner feared their partners' responses to exploring sexuality. However, most women were excited to be single and to have the time and space to explore their feelings about their sexuality.

As with Karina's example, single mothers incorporated discussions about sexuality with their children as part of larger conversations about equity and inclusion. Conversations that challenge dominant norms surrounding femininity and masculinity (Butler, 2004; Feinberg, 1998; Namaste, 2005; Stryker, 2008) are also important in demonstrating that there are many ways of knowing and being. Daniela, even though she had partnered with a woman and dated a person who was transgendered, did want to be labelled:

Daniela: I think I'm just open-minded. I guess I don't know. Maybe questioning. I don't know what.

Jenn: Just feel comfortable in that space?

D: Yeah. I think maybe I'm just, like, open-minded to being in a relationship with someone I like.

J: Yeah, regardless of their...

D: Regardless of their gender.

J: So you wouldn't identify a certain way?

D: No, I wondered for a long time if I was bisexual but I don't quite think that either. So I haven't quite figured out a preference.

Many women reported that the men they had been partnered with insisted on restrictive binary codes of gender behaviour for their children and being single freed them from this limitation. However, some interesting challenges emerged from explorations of sexuality. A single queer mother, or a single mother exploring her sexuality, must endure a constant process of coming out because she has no same-sex, same-gender, or transgender partner that would more easily identify her as queer. Sexuality, it seems, is identified in society by another - by a relationship with someone else as opposed to the self.

For years, much pressure has been put on queer communities and queer parents in particular to prove they are as good as heterosexual families. Research has often been formulated to make this point. Epstein (2009a) challenges this sameness debate and builds on pivotal findings by Stacey and Biblarz (2001) that demonstrate the unique differences of children who were raised with lesbian and gay parents. In this study, children exhibited increased self-esteem, more empathy towards social justice issues, more interest in being an ally, and less conformity towards restrictive gender roles and responsibilities. Epstein's (2009b) edited collection about queer parenting contributes a unique and diverse array of experiences, including barriers and rich possibilities for many kinds of families.

Many women were also involved in on-campus initiatives, programs, and activist groups that sought to challenge oppressive systems in society, such as anti-ableism, anti-racist, antiheterosexist, and union groups. These venues gave women a space to validate their life 
experiences and contribute to social activism in an educational setting. One of the difficult binaries that arose in the study was women feeling as though they were expected to separate both the challenges and rewards of their personal lives from their academic lives. Most women were proud of their identities, the obstacles they had overcome, and the children they were raising either on their own or with the assistance of friends and family members. Indeed, most women entered or re-entered academia because of their children. For many women, going to university was the best chance they had at being able to provide for their children as a sole-support mother with only one income.

Many of the co-participants in the study were already studying in critical fields such as Social Work, Women and Gender Studies, Aboriginal Studies, Diaspora Studies, and Sociology, or wanted to move into "helping professions". As they put it, having these difficult and rewarding experiences in their lives made them aware of how marginalized people are denied access to resources and are stigmatized in society. Their own struggles gave them a unique perspective with respect to understanding of, identification with, and empathy toward those experiencing barriers. Sally talked about her own struggles and her opportunity to give back now by being in the field of social work. Also, she felt that becoming pregnant at 16 was not the negative experience characterized within dominant discourse:

I often say getting pregnant at 16 saved my life, even though I was in high school. I was involved in a lot of dangerous activities and so I think, yeah, actually it was having a child that made my commitment to it (education) even greater. I remember I hung my high school diploma over his crib when he was young...that brings up a lot of emotions. I remember how proud I was of that stupid high school diploma, before even knowing the benefits of post-secondary education. I didn't even think I would get in.

Many of these single mother students came into university through an access program designed to provide support for non-traditional students. These programs often recognize historic and current-day systemic barriers due to issues such as homelessness, poverty, racism, colonialism, and discrimination against single mothers (Antone, 2003; Brathwaite, 2003; Stallberg-White, 2003). Many participants reported being very conscious of introducing the university to their children and brought their children with them to campus whenever they could. First, they wanted their children to see where they spent so much of their time and energy. But just as important, they wanted to normalize the university for their children. Many single mother students had not imagined going to university and belonged to historically disadvantaged groups without access to post-secondary education. They did not want their children to feel that university was not an option for them, the way that many of them had. Further, these women challenged the assumption that there should be a divide between individuals and their lives on the one hand, and the student and the university on the other. These aspects of identity were interconnected and added to the richness of possibilities in both the education system and their larger life experiences. 
International Journal of Child, Youth and Family Studies (2011) 3 \& 4: 410-431

\section{Conclusion}

While real structural and attitudinal barriers exist in society and in education, opportunities also exist in these spaces to create a new narrative of single motherhood that challenges society's dominant image. This new narrative encapsulates a more complex and strengths-based analysis of single mothers' lives, bringing attention to the positive impact of these experiences and contributing to a new discourse of the family in the community.

During the 1800s and 1900s, and even still today, single mothers have been referred to as unwed mothers, deserted wives, or widows (Brady, 2007). Women and mothers have been defined by their relationship to a partner, or the lack thereof, never as a person or family unit in their own right. Even the category of single motherhood needs to be challenged since its very definition suggests single mother as Other, while the discourse of motherhood alone reinforces the dominant nuclear family norms.

Single mother families in this study challenge previous research which only looks at their connections to the state. Despite politically driven images of single mothers being a drain on the state, in contrast, only two women received social assistance. This study expanded its lens to explore other areas of oppression such as racism, ableism, and heterosexism but also focused on strengths, what made single mother families unique and strong. By not approaching this family unit from a deficit model, important themes emerged that contribute to a socially just family structure and larger connections to community were made.

While this study looked at the experiences of students, we need to be careful not to assume that education is the end-all solution to the barriers faced by marginalized populations. For example, many do not have access to foundational, formal education, may have already acquired education in another country (the credentials for which may not be recognized in Canada due to imperialist policies), or might distrust the education system because of colonial policies and practices. Some might not have housing and be fighting for survival on a daily basis. Also, while most women in this study benefited from attending university and found empowering and consciousness-raising spaces, not all spaces were considered safe or free from discrimination (for further discussion of the barriers faced by single mother students, see Ajandi, 2011). However, the aim of this paper was to present an alternative discourse that emerged in this study, which other single mothers might identify with, and to disrupt the dominant themes of victimhood, poverty, and neglect that are prevalent in the single motherhood canon. As I am continuously contacted by others in the field who are either single mothers or doing research with single mother students, I look forward to seeing more work that complicates rather than simplifies the multiple realities of our lives. 
International Journal of Child, Youth and Family Studies (2011) 3 \& 4: 410-431

\section{References}

Abele, F., Dittburner, C., \& Graham, K. A. (2000). Towards a shared understanding in the policy discussion about Aboriginal education. In M. B. Castellano, L. Davis, \& L. Lahache (Eds.), Aboriginal education: Fulfilling the promise (pp. 3-24). Vancouver, BC: UBC Press.

Abramovitz, M. (1996). Regulating the lives of women: Social welfare policy from colonial times to the present. Cambridge, MA: South End Press.

Acker, S. (2001). In/out/side: Positioning the researcher in feminist qualitative research. Resources for feminist research, 28(3/4), 153-172.

Adair, V. C. (2001). Poverty and the (broken) promise of higher education. Harvard Educational Review, 71(2), 217-239.

Ajandi, J. (2009). Disrupting the "traditional student” discourse: Poverty, education, and the state. Esurio: Journal of Hunger and Poverty 1(2), 16 p. Retreived from http://www.esurio.ca/ojs-2.2/index.php/esurio/article/view/44/91.

Ajandi, J. (2011). Overcoming barriers and finding strengths: The lives of single mother students in university (Doctoral dissertation, Ontario Institute for Studies in Education, University of Toronto). Retrievable from ProQuest Dissertations and Theses database.

Anderson, K. (2000). A recognition of being: Reconstructing Native womanhood. Toronto: Sumach Press.

Antone, E. M. (2003). Aboriginal students in the transitional year programme at the University of Toronto. In K. S. Brathwaite (Ed.), Access and equity in the university (pp. 165-187). Toronto: Canadian Scholars’ Press.

Bannerji, H., Carty, L., Dehli, K., Heald, S., \& McKenna, K. (1991). Unsettling relations: The university as a site of feminist struggles. Toronto: Women’s Press.

Barnoff, L., \& Moffatt, K. (2007). Contradictory tensions in anti-oppression practice within feminist social services. Affilia, 22(1), 56-70.

Bashevkin, S. (2002). Welfare hot buttons: Women, work, and social policy reform. Toronto: University of Toronto Press.

Baskin, C. (2005). Circles of inclusion: Aboriginal world views in social work education (Doctoral dissertation). Retrieved from ProQuest Dissertations and Theses database (AAT NR27745). 
International Journal of Child, Youth and Family Studies (2011) 3 \& 4: 410-431

Baskin, C. (2008). “I don’t know what hurts more - to shut up or speak up”: Aboriginal female learners in the academy. In A. Wagner, S. Acker, \& K. Mayuzumi (Eds.), Whose University is it, anyway? Power and privilege on gendered terrain (pp. 27-43). Toronto: Sumach Press.

Berman, R., Silver, S., \& Wilson, S. (2007). "Don’t look down on me because I have one”Young mothers resisting the discourse of "a young mother is a bad mother". Journal of the Association for Research on Mothering, 9(1), 42-52.

Bezanson, K. (2006). Gender, the state, and social reproduction: Household insecurity in neoliberal times. Toronto: University of Toronto Press.

Bishop, A. (2002). Becoming an Ally: Breaking the cycle of oppression in people. Halifax, NS: Fernwood.

Brady, M. (2007). Institutionalized individualism and the care of the self: Single mothers and the state. In C. Howard (Ed.), Contested individualization: Debates about contemporary personhood (pp. 187-208). New York: Palgrave Macmillan.

Brathwaite, K. (2003). Access and equity in the university: An introduction. In K. S. Brathwaite (Ed.), Access and equity in the university (pp. 11-22). Toronto: Canadian Scholars’ Press.

Butler, J. (2004). Undoing gender. New York: Routledge.

Caragata, L. (2009). Lone mothers: Policy responses to build social inclusion. In M. G. Cohen \& J. Pulkingham (Eds.), Public policy for women: The state, income security, and labour market issues (pp. 162-183). Toronto: University of Toronto Press.

Carniol, B. (2000). Case critical: Challenging social services in Canada. Toronto: Between the Lines.

Carty, L. (1992). Black women in academia: A statement from the periphery. In H. Bannerji, L. Carty, K. Dehli, S. Heald, \& K. McKenna (Eds.), Unsettling relations: The university as a site of feminist struggles (pp. 13-23). Toronto: Women's Press.

Collins, P. H. (2000). Black feminist thought: Knowledge, consciousness, and the politics of empowerment. New York: Routledge.

Cull, R. (2006). Aboriginal mothering under the state’s gaze. In D. Lavell-Harvard \& J. Corbiere Lavell (Eds.), "Until our hearts are on the ground”: Aboriginal mothering, oppression, resistance and rebirth (pp. 141-156). Toronto: Demeter Press.

Dei, G. J. S., James, I. M., Karumanchery, L. L., James-Wilson, S., \& Zine, J. (2000). Removing the margins: The challenges and possibilities of inclusive schooling. Toronto: Canadian Scholars’ Press. 
International Journal of Child, Youth and Family Studies (2011) 3 \& 4: 410-431

Dua, E. (1999). Beyond diversity: Exploring the ways in which the discourse of race has shaped the institution of the nuclear family. In E. Dua \& A. Robertson (Eds.), Scratching the surface: Canadian anti-racist feminist thought (pp. 237-259). Toronto: Women’s Press.

Eichler, M. (2010). What is housework? In M. Eichler, P. Albanese, S. Ferguson, N. Hyndman, L. Liu, \& A. Matthews (Eds.), More than it seems: Household work and lifelong learning (pp. 21-48). Toronto: Women’s Press.

Epstein, R. (2009a). Introduction. In R. Epstein (Ed.), Who's your daddy? And other writings on queer parenting (pp. 13-32). Toronto: Sumach Press.

Epstein, R. (Ed.). (2009b). Who's your daddy? And other writings on queer parenting. Toronto: Sumach Press.

Eyre, L. (2000). The discursive framing of sexual harassment in a university community. Gender and Education, 12(3), 293-307.

Feinberg, L. (1998). Trans liberation: Beyond pink or blue. Boston: Beacon Press.

Fook, J. (2002). Social work: Critical theory and practice. London: Sage.

Foucault, M. (1977). Discipline and punish: The birth of the prison. London: Penguin.

Giroux, H. (2002). Neoliberalism, corporate culture and the promise of higher education: The University as a democratic public sphere. Harvard Educational Review, 72(4), 1-31.

Graveline, F. J. (1998). Circleworks: Transforming Eurocentric consciousness. Halifax, NS: Fernwood.

Griffith, A. I., \& Smith, D. E. (1991). Constructing cultural knowledge: Mothering as discourse. In J. Gaskell \& A. McLaren (Eds.), Women and education (2nd ed., pp. 81-97). Calgary, AB: Detselig Enterprises, Ltd.

Henry, F., \& Tator, C. (2009). Racism in the Canadian university: Demanding social justice, inclusion, and equity. Toronto: University of Toronto Press.

hooks, b. (1994). Teaching to transgress: Education as the practice of freedom. New York: Routledge.

Ife, J. (1997). Rethinking social work: Towards critical practice. Melbourne: Addison-Wesley Longman.

James, C. E. (2003). Becoming “insiders": Racialized students in the academy. In K. S. Brathwaite (Ed.), Access and equity in the university (pp. 139-164). Toronto: Canadian Scholars' Press. 
International Journal of Child, Youth and Family Studies (2011) 3 \& 4: 410-431

Jones-DeWeever, A. A. (2005). When the spirit blooms: Acquiring higher education in the context of welfare reform. Journal of Women, Politics \& Policy, 3, 113-133.

Kelly, D. M. (2000). Pregnant with meaning: Teen mothers and the politics of inclusive schooling. New York: Peter Lang.

Khosla, P. (2008). If low-income women of colour counted in Toronto. In M. A. Wallis \& S. Kwok (Eds.), Daily struggles: The deepening racialization and feminization of poverty in Canada (pp. 223-247). Toronto: Canadian Scholars’ Press.

Kirby, S., \& McKenna, K. (1989). Experience research social change: Methods from the margins. Toronto: Garamond Press.

Kitzinger, C. (1993). Beyond the boundaries: Lesbians in academe. In J. Glazer, E. M. Bensimon, \& B. Townsend (Eds.), Women in higher education: A feminist perspective (pp. 437-446). Needham Heights, MA: Ginn Press.

Lavell, D. M. H., \& Lavell, J. C. (2006). Aboriginal women vs. Canada: The struggle for our mothers to remain Aboriginal. In D. M. H. Lavell \& J. C. Lavell (Eds.), "Until our hearts are on the ground": Aboriginal mothering, oppression, resistance and rebirth (pp. 184195). Toronto: Demeter Press.

Lightman, E., \& Baines, D. (1996). White men in blue suits: Women's policy in Conservative Ontario. Canadian Review of Social Policy, 51, 145-151.

Lightman, E., Herd, D., Um, S., \& Mitchell, A. (2009). Post-secondary education and social assistance in Ontario. Canadian Social Work Review, 26(1), 97-113.

Little, M. H. (1998). 'No car, no radio, no liquor permit': The moral regulation of single mothers in Ontario, 1920-1997. Toronto: Oxford University Press.

Mahtani, M. (2004). Mapping race and gender in the academy: The experiences of women of colour faculty and graduate students in Britain, the U.S. and Canada. Journal of Geography in Higher Education, 28(1), 91-99.

Mitchell, T. (2003). If I survive, it will be despite welfare reform: Reflections of a former welfare student. In V. C. Adair \& S. L. Dahlberg (Eds.), Reclaiming class: Women, poverty, and the promise of higher education in America (pp. 113-118). Philadelphia: Temple University Press.

Mojab, S. (2002). Equity coordinator: Change agent in an unyielding power structure. In E. Hannah, L. Paul, \& S. Vethamany-Globus (Eds.), Women in the Canadian academic tundra: Challenging the chill (pp. 162-167). London, ON: McGill-Queen’s University Press. 
International Journal of Child, Youth and Family Studies (2011) 3 \& 4: 410-431

Monture-Angus, P. (2001). In the way of peace: Confronting "whiteness” in the university. In R. Luther, E. Whitmore, \& B. Moreau (Eds.), Seen but not heard: Aboriginal women and women of colour in the academy (pp. 29-49). Ottawa, ON: CRIAW.

Mullaly, B. (2002). Challenging oppression: A critical social work approach. Toronto: Oxford University Press.

Namaste, V. (2005). Sex change, social change: Reflections on identity, institutions, and Imperialism. Toronto: Women's Press.

Ng, R., Staton, P., \& Scane, J. (Eds.). (1995). Anti-racism, feminism, and critical approaches to education. London: Bergin and Garvey.

Oliver, M., \& Barnes, C. (2010). Disability studies, disabled people and the struggle for inclusion. British Journal of Sociology of Education, 31(5), 547-560.

Pandey, S., Zhan, M., \& Kim, Y. (2006). Bachelor's degree for women with children: A promising pathway to poverty reduction. Equal Opportunities International, 25(7), 488-505.

Pandey, S., Zhan, M., Neely-Barnes, S., \& Menon, N. (2000). The higher education option for poor women with children. Journal of Sociology and Social Welfare, 27(4), 109-162.

Peters, W. (2005). Queer identities: Rupturing identity categories and negotiating meanings of queer. Canadian Woman Studies / les cahiers de la femme, 24(2/3), 102-107.

Pillow, W. S. (2004). Unfit subjects: Educational policy and the teen mother. New York: RoutledgeFalmer.

Potts, K., \& Brown, L. (2005). Becoming an anti-oppressive researcher. In L. Brown \& S. Strega (Eds.), Research as resistance: Critical, Indigenous, and anti-oppressive approaches (pp. 255-286). Toronto: Canadian Scholars’ Press.

Rajagopal, I. (2002). Hidden academics: Contract faculty in Canadian universities. Toronto: University of Toronto Press.

Razack, N. (2002). Transforming the field: Critical anti-racist and anti-oppressive perspectives for the human services practicum. Halifax, NS: Fernwood.

Reed, M. J., Lewis, T., \& Lund-Lucas, E. (2006). Access to post-secondary education and services for students with learning disabilities: Student, alumni and parent perspectives from two Ontario universities. Higher Education Perspectives, 2(2), 50-65. Retrieved from http://hep.oise.utoronto.ca/index.php/hep/article/view/617

Reid, C. (2004). Advancing women's social justice agendas: A feminist action research framework. International Journal of Qualitative Methods, 3(3), 1-22. 
International Journal of Child, Youth and Family Studies (2011) 3 \& 4: 410-431

Rezai-Rashti, G. (1997). Gender equity issues and minority students. Orbit, 28(1), 24-25. Toronto: OISE/UT.

Ristock, J., \& Pennell, J. (1996). Community research as empowerment: Feminist links, postmodern interruptions. Toronto: Oxford University Press.

Roberts, D. (1999). Killing the Black body: Race, reproduction, and the meaning of liberty. New York: Vintage Books.

Rogowski, S. (2008). Social work with children and families. Towards a radical/critical practice. Social Work in Action, 20(1), 17-28.

Salmon, A. (2007). Walking the talk: How participatory interview methods can democratize research. Qualitative Health Research, 17(7), 982-993.

Sapon-Shevin, M. (2007). Widening the circle: The power of inclusive classrooms. Boston: Beacon Press.

Schwartz, S., \& Finnie, R. (2002). Student loans in Canada: An analysis of borrowing and repayment. Economics of Education Review, 21, 497-512.

Shanahan, T., \& Jones, G. A. (2007). Shifting roles and approaches: Government coordination of post-secondary education in Canada, 1995-2000. Higher Education Research \& Development, 26(1), 21-43.

Sidel, R. (2006). Unsung heroines: Single mothers and the American dream. Berkeley, CA: University of California Press.

Smith, L. T. (1999). Decolonizing methodologies: Research and Indigenous Peoples. New York: Zed Books.

Stacey, J., \& Biblarz, T. J. (2001). (How) Does the sexual orientation of parents matter? American Sociological Review, 66(2), 159-183.

Stallberg-White, C. (2003). From outsider to insider: Toward a model of transition for nontraditional university students. In K. S. Brathwaite (Ed.), Access and equity in the university (pp. 181-187). Toronto: Canadian Scholars’ Press.

Statistics Canada. (2006). Study: Who gets student loans? The Daily: Friday, March 24, 2006. Retrieved from http://www.statcan.ca/Daily/English/060324/d060324c.htm

Stryker, S. (2008). Transgender history. Berkeley, CA: Seal Press. 
International Journal of Child, Youth and Family Studies (2011) 3 \& 4: 410-431

Wagner, A. (2008). The invisible cloak: Exploring the impact of trauma on women learners in higher education. In A. Wagner, S. Acker, \& K. Mayuzumi (Eds.), Whose university is it, anyway? Power and privilege on gendered terrain (pp. 90-103). Toronto: Sumach Press.

Wagner, A., \& Magnusson, J. L. (2005). Neglected realities: Exploring the impact of women's experiences of violence on learning in sites of higher education. Gender and Education, 17(4), 449-461.

Waldner, L. K. (2003). If you want me to pull myself up, give me bootstraps. In V. C. Adair \& S. L. Dahlberg (Eds.), Reclaiming class: Women, poverty, and the promise of higher education in America (pp. 97-110). Philadelphia: Temple University Press.

Wane, N. N. (2000). Reflections on the mutuality of mothering: Women, children, and Othermothering. Journal for Research on the Association of Mothering, 2(2), 105-116.

Wehbi, S. (2009). Reclaiming our agency in academia: Engaging in the scholarship of teaching in social work. Social Work Education, 28(5), 502-511.

Wilkinson, S. (1998). Focus groups in feminist research: Power, interaction, and the coconstruction of meaning. Women's Studies International Forum, 21(1), 111-125.

Wong, R. (2004). Knowing through discomfort: A mindfulness based social work pedagogy. Critical Social Work, 5(1). Retrieved from http://www.uwindsor.ca/criticalsocialwork/knowing-through-discomfort-a-mindfulnessbased-critical-social-work-pedagogy

Zhan, M., \& Pandey, S. (2004a). Economic well-being of single mothers: Work first or postsecondary education? Journal of Sociology \& Social Welfare, 31(3), 87-113.

Zhan, M., \& Pandey, S. (2004b). Postsecondary education and economic well-being of single mothers and single fathers. Journal of Marriage and Family, 66(3), 661-673. 